\title{
Hyperthermia Effect of Nanoclusters Governed by Interparticle Crystalline Structures
}

Misun Jung ${ }^{1}$, Sang Hun Lee ${ }^{1}$, Dae Young Song ${ }^{1}$, Sunghwi Kang ${ }^{2,3}$, Tae-Hyun Shin ${ }^{4}$, Jin-sil Choi ${ }^{1, *}$

1. Dept. of Chemical and Biological Engineering, Hanbat National University

34158 Daejeon, Republic of Korea

2. Center for Nanomedicine, Institute for Basic Science (IBS), 03722 Seoul, Republic of Korea

3. Department of Chemistry, Yonsei University, 03722 Seoul, Republic of Korea

4. Research Institute of Radiological Science, Severance Hospital, Yonsei University College of Medicine, 03722 Seoul, Republic of Korea 
Table S1. Comparison of hyperthermic effects of various magnetic nanoparticles.

\begin{tabular}{|c|c|c|c|c|c|c|c|c|c|}
\hline \multicolumn{2}{|c|}{ Material } & Size (nm) & Shape & Magnetism & $\begin{array}{c}\text { Frequency } \\
,\end{array}$ & Amplitude, & $\begin{array}{l}\text { Reported } \\
\text { SAR/SLP }\end{array}$ & $\begin{array}{l}\text { Calculated } \\
\text { ILP }\end{array}$ & Reference \\
\hline \multirow[t]{21}{*}{$\begin{array}{c}\text { Feridex } \\
\left(\mathrm{FeO}_{x}\right)\end{array}$} & \multirow[t]{2}{*}{ Isolated } & \multirow[t]{2}{*}{ Undefined } & \multirow[t]{2}{*}{ Sphere } & \multirow[t]{2}{*}{ Superpara } & \multirow[t]{2}{*}{500} & \multirow[t]{2}{*}{37.4} & 115 & 0.164 & $\begin{array}{c}\text { Nano Lett. 2012, } \\
12,3716-3721\end{array}$ \\
\hline & & & & & & & 122 & 0.174 & Our study \\
\hline & Isolated & 25 & Sphere & Superpara & \multirow[t]{3}{*}{500} & \multirow[t]{3}{*}{37.4} & 1049.0 & 1.58 & $\begin{array}{c}\text { Our study } \\
\text { (Synthesized, } \\
\text { see Figure S8) }\end{array}$ \\
\hline & Assembled & 25 & Irregular & Superpara & & & 231.7 & 0.331 & $\begin{array}{c}\text { Our study } \\
\text { (Synthesized, } \\
\text { see Figure S10) }\end{array}$ \\
\hline & Clustered & 25 & Irregular & Ferro & & & 1264 & 1.81 & $\begin{array}{c}\text { Our study } \\
\text { (NC_25) }\end{array}$ \\
\hline & \multirow[t]{7}{*}{ Isolated } & 40 & Sphere & Ferro & 510 & 10 & 960 & 1.88 & $\begin{array}{c}\text { J. Magn. Magn. } \\
\text { Mater. 2005, } \\
293,80-86\end{array}$ \\
\hline & & 9.1 & Sphere & Superpara & 700 & 24.8 & 360 & 0.86 & $\begin{array}{l}\text { J. Am. Chem. } \\
\text { Soc. 2007, } 129 \text {, } \\
2628-2635\end{array}$ \\
\hline & & $\begin{array}{c}\text { Not } \\
\text { provided }\end{array}$ & Spheres & Superpara & & & 140 & 0.11 & \\
\hline & & $41 \times 7$ & \multirow[t]{2}{*}{ Rod } & Superpara & \multirow[t]{3}{*}{310} & \multirow[t]{3}{*}{63.66} & 550 & 0.43 & \multirow{3}{*}{$\begin{array}{c}\text { J. Phys. Chem. } \\
\text { C 2016, 120, } \\
\text { 10086-10093 }\end{array}$} \\
\hline & & $65 \times 5.7$ & & Superpara & & & 862 & 0.68 & \\
\hline & & $\begin{array}{c}\text { Not } \\
\text { provided }\end{array}$ & Cube & Superpara & & & 314 & 0.25 & \\
\hline & & 14.91 & Hexagon & Superpara & \multirow[t]{2}{*}{420} & \multirow[t]{2}{*}{26.9} & 364.5 & 1.19 & \multirow{2}{*}{$\begin{array}{c}\text { ACS Nano 2019, } \\
13,6383-6395\end{array}$} \\
\hline & \multirow[t]{5}{*}{ Clustered } & 80.10 & Hexagon & Superpara & & & 493.8 & 1.62 & \\
\hline & & 26 & \multirow[t]{2}{*}{ Irregular } & \multirow[t]{2}{*}{ Superpara } & \multirow[t]{2}{*}{100} & \multirow[t]{2}{*}{9.3} & 12.2 & 1.41 & \multirow{2}{*}{$\begin{array}{c}\text { Nanoscale 2018, } \\
10,21262- \\
21274\end{array}$} \\
\hline & & 34 & & & & & 11.5 & 1.32 & \\
\hline & & 24 & Irregular & Superpara & 520 & 24 & 1604 & 5.35 & $\begin{array}{c}\text { Small 2014, 10, } \\
3325-3337\end{array}$ \\
\hline & & 28 & Irregular & Superpara & 700 & 21.5 & 1994 & 6.16 & $\begin{array}{l}\text { J. Phys. Chem. } \\
\text { C 2012, 116, } \\
15702-15712 \\
\end{array}$ \\
\hline & \multirow{4}{*}{ Assembled } & Undefined & Chain & Ferro & 765 & 23.9 & 1500 & 3.43 & $\begin{array}{l}\text { J. Phys. Chem. } \\
\text { C 2014, } 118, \\
5927-5934\end{array}$ \\
\hline & & 51 & Anisotropic & \multirow[b]{2}{*}{ Ferro } & \multirow[b]{2}{*}{302} & \multirow[b]{2}{*}{23.8} & 253 & 1.48 & ACS Nano 2017, \\
\hline & & 90 & Isotopic & & & & 184 & 1.08 & $\begin{array}{c}11 \\
12121-12133\end{array}$ \\
\hline & & 18 & Irregular & Superpara & 145 & 33.6 & 2101.7 & 0.368 & $\begin{array}{c}\text { Langmuir 2016, } \\
32,1201-1213\end{array}$ \\
\hline $\mathrm{MnFe} \Omega$ & Isolated & 10 & Sphere & Superpara & 300 & 15 & 136 & 2.01 & $\begin{array}{c}\text { J. Biomed. } \\
\text { Mater. Res.: } \\
\text { Part B 2007, 81, } \\
12-22\end{array}$ \\
\hline $\mathrm{NInFe}_{2} \mathrm{O}$ & Assembled & 100 & Sphere & Ferro & 114 & 114.9 & 1618.8 & 1.07 & $\begin{array}{c}\text { ACS Appl. } \\
\text { Mater. } \\
\text { Interfaces 2014, } \\
6,16867-16879\end{array}$ \\
\hline CoMn- & Isolated & 14.8 & Hexagon & Superpara & 420 & 26.9 & 997.2 & 3.43 & ACS Nano $\mathbf{2 0 1 9}$ \\
\hline ferrite & cluster & 78.67 & Custer & Superpara & 420 & 26.9 & 1237.0 & 4.26 & $13,6383-6395$ \\
\hline $\mathrm{MnFe}_{3} \mathrm{O}_{4}$ & Isolated & 15 & Sphere & Superpara & & & 411 & 0.587 & Nano Lett. 2012, \\
\hline $\begin{array}{c}\mathrm{MnFe}_{2} \mathrm{O}_{4} \\
\text { (a) } \mathrm{CoFe}_{2} \mathrm{O}_{4}\end{array}$ & Isolated & 15 & $\begin{array}{c}\text { Sphere } \\
\text { core-shell }\end{array}$ & Superpara & 500 & 37.4 & 3034 & 4.33 & $12,3716-3721$ \\
\hline $\mathrm{Zn}_{0.4} \mathrm{Fe}_{2.6} \mathrm{O}_{4}$ & Isolated & 18 & Cube & Superpara & & & 1860 & 2.65 & \\
\hline $\mathrm{ZnFe}_{2} \mathrm{O}_{4}$ & Assembled & 100 & Sphere & Ferro & 114 & 114.9 & 1139.0 & 0.76 & $\begin{array}{c}\text { ACS Appl. } \\
\text { Mater. } \\
\text { Interfaces } \mathbf{2 0 1 4}, \\
6,16867-16879\end{array}$ \\
\hline $\mathrm{Zn}_{0.4} \mathrm{Fe}_{2.6} \mathrm{O}_{4}$ & Isolated & 22 & Sphere & Superpara & 500 & 37.4 & 500 & 0.715 & Nano Lett. 2012, \\
\hline $\mathrm{Zn}_{0.4} \mathrm{Fe}_{2.6} \mathrm{O}_{4}$ & Isolated & 60 & Cube & Ferro & & & 4060 & 5.8 & $12,7,3716-$ \\
\hline (a) $\mathrm{CoFe}_{2} \mathrm{O}_{4}$ & Isolated & 60 & $\begin{array}{c}\text { Cube } \\
\text { core-shell }\end{array}$ & Ferro & & & 10600 & 15.15 & 3721 \\
\hline
\end{tabular}




\section{Zeta potential of NCs}

The NCs are coordinated by PAA and possess a negative surface charge owing to the rich PAA carboxylates.

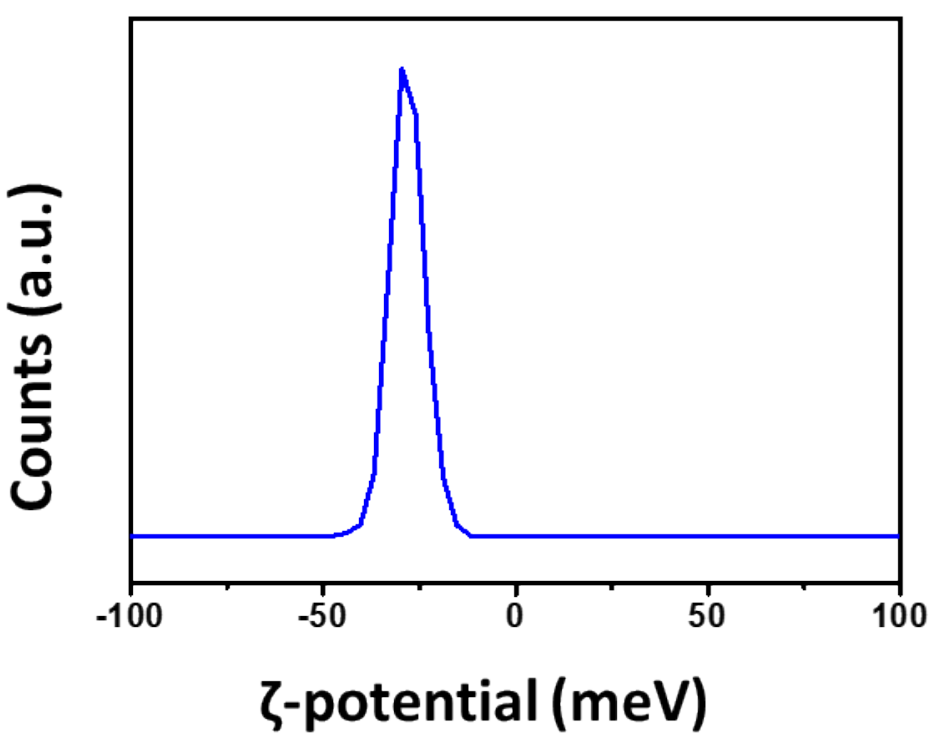

Figure S1. ל-potential of NCs. 


\section{Analysis of crystal structure of obtained NCs}

The characterization results of the NCs are shown in Figure S2. The XRD pattern of the NCs was well matched to that of bulk $\mathrm{Fe}_{3} \mathrm{O}_{4}$ (JCPDS \#:01-079-0417), indicating a spinel crystalline structure.

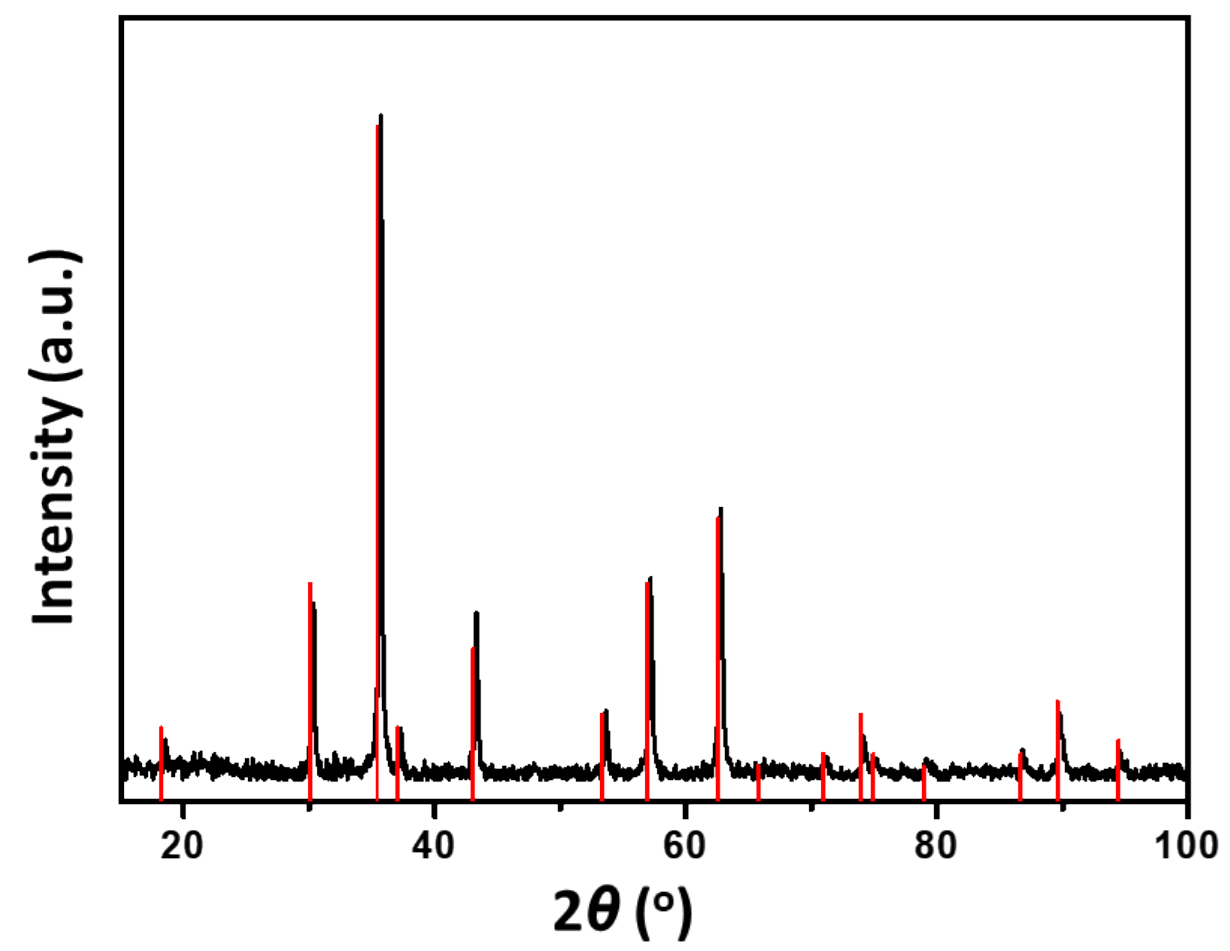

Figure S2. XRD pattern of as-synthesized NCs. All peaks are matched with JCPDS card reference number 01-079-0417 (magnetite). 
The NC is examined via high-resolution X-ray photoelectron spectroscopy (XPS). The XPS spectrum for $\mathrm{Fe} 2 \mathrm{p}$ of the $\mathrm{NC}$ reveals two peaks, which are attributed to $\mathrm{Fe} 2 \mathrm{p}_{3 / 2}(c a .710 .7 \mathrm{eV})$ and $\mathrm{Fe} 2 \mathrm{p}_{1 / 2}(c a$. $724.5 \mathrm{eV}$ ). The absence of the satellite peak at $719 \mathrm{eV}$ confirms the presence of both $\mathrm{Fe}^{2+}$ and $\mathrm{Fe}^{3+}$ ions in the crystalline.

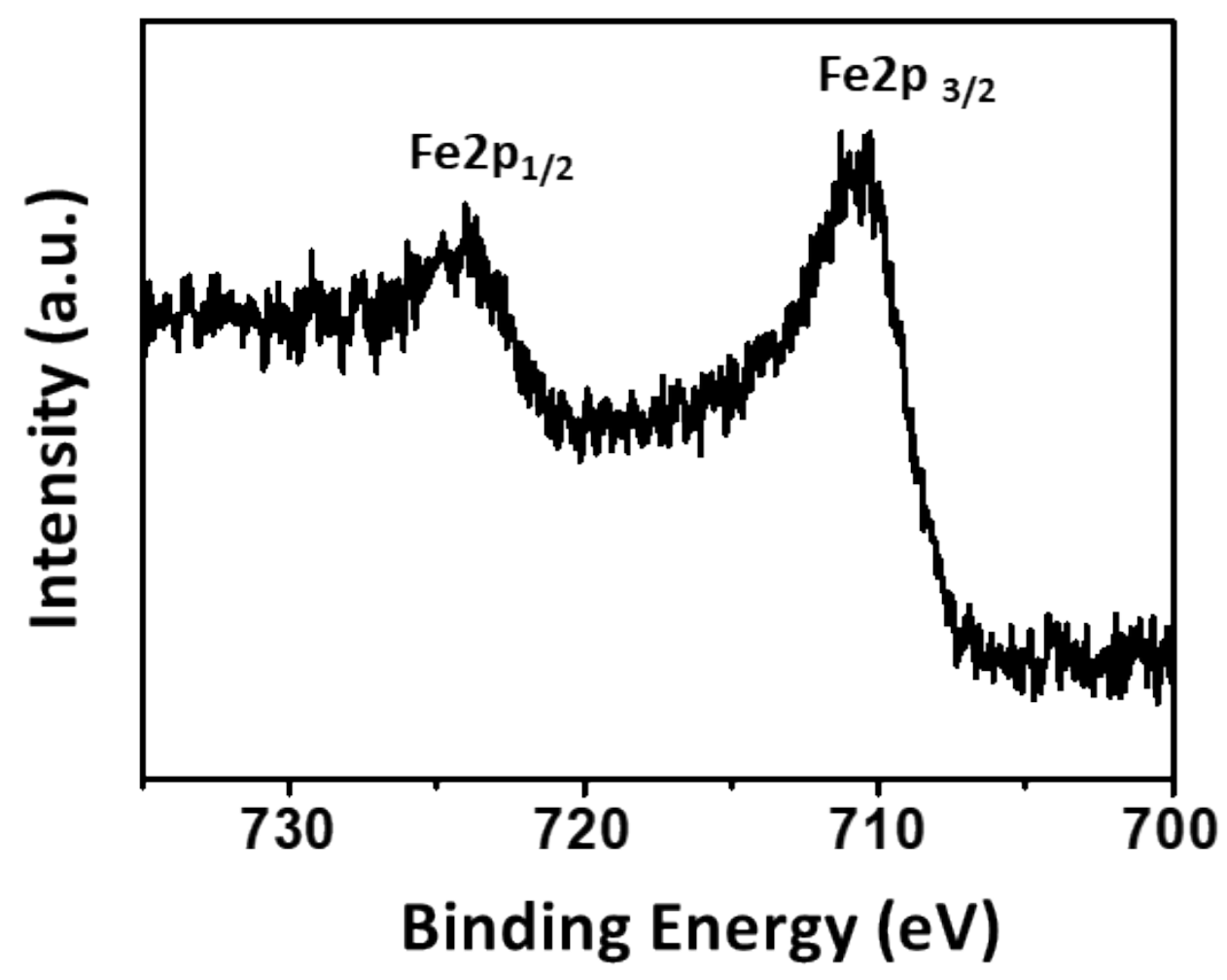

Figure S3. XPS Fe 2p spectrum of as-synthesized NCs. 


\section{TEM image of NCs}

The NCs were composed of compactly assembled iron oxide nanoparticles (ca. $7 \mathrm{~nm})$. The size of unit nanoparticles at the boundary region was measured and averaged.

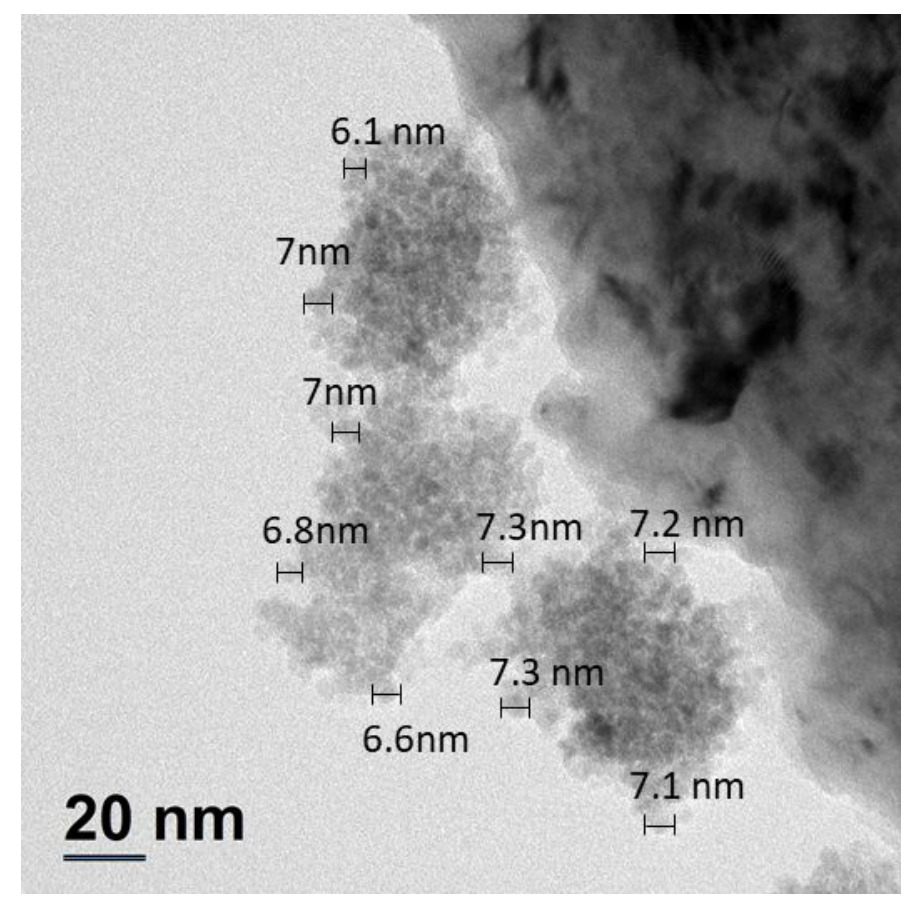

Figure S4. TEM image of NCs. 


\section{Stability test of NCs in aqueous solutions at different pHs and salt concentrations and in saline}

The stability of the NCs in an aqueous solution was examined by checking their hydrodynamic size


buffer for $\mathrm{pH} 9)$ and salt concentrations $(0-200 \mathrm{mM} \mathrm{NaCl})$ after $1 \mathrm{~h}$ of incubation. The NCs were stably dispersed in an aqueous solution at $\mathrm{pH} 4-9$ and salt concentrations up to $200 \mathrm{mM}$ (c.f. saline: $153 \mathrm{mM}$ $\mathrm{NaCl}$ ). The hydrodynamic size of the NCs was maintained in saline after $1 \mathrm{~h}$ of incubation compared to that in DIW.
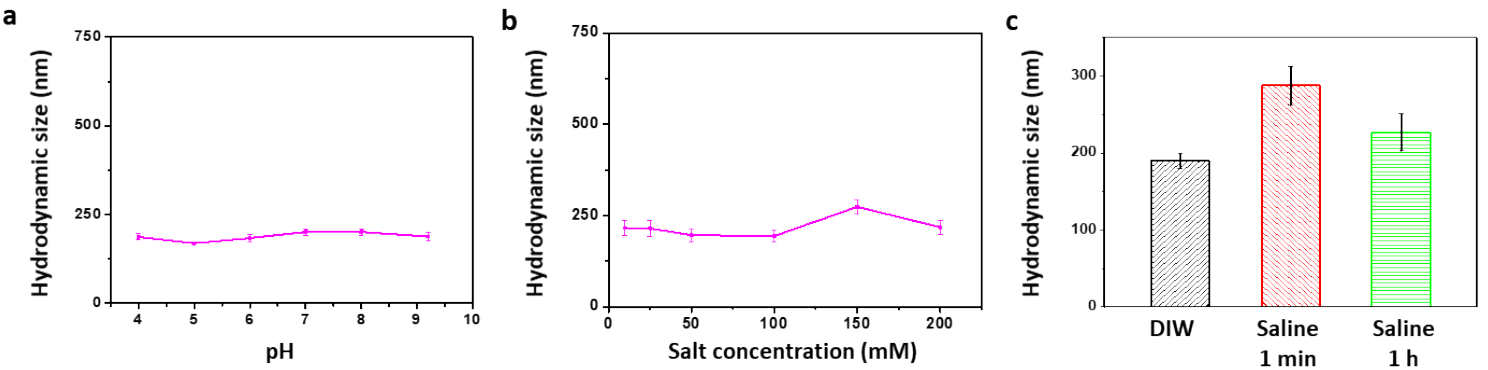

Figure S5. Hydrodynamic size changes of NCs under different (a) pHs and (b) salt concentrations and (c) in saline. 
Hydrodynamic size of NCs in aqueous solutions

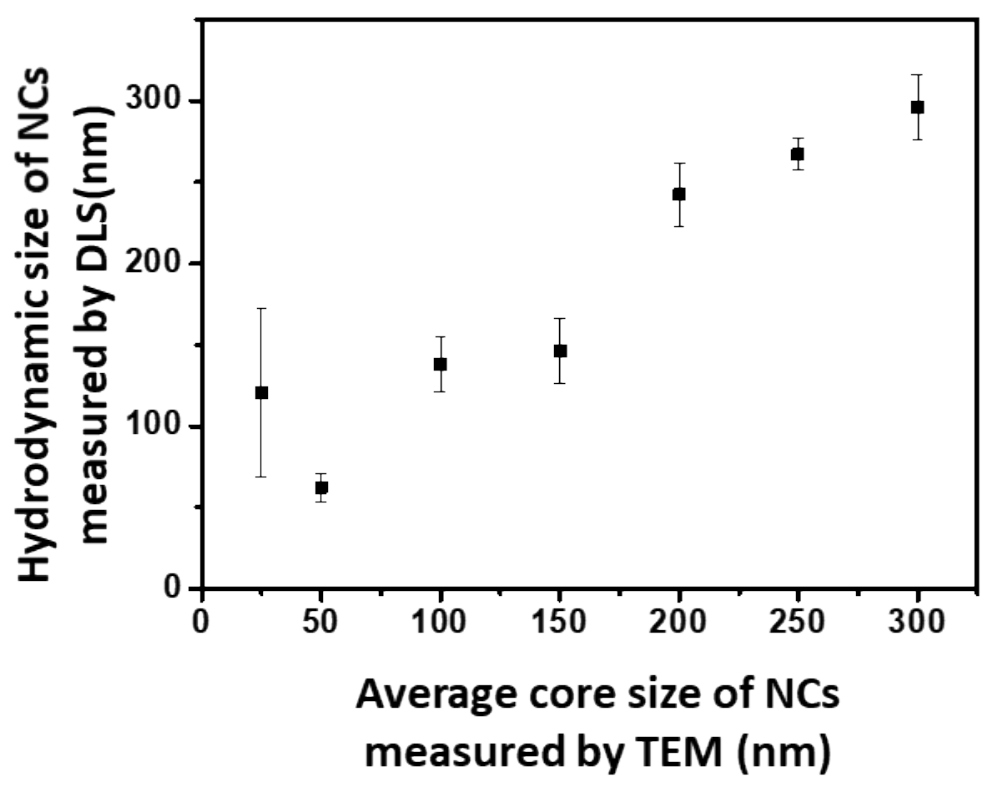

Figure S6. Hydrodynamic size of NCs. 


\section{TEM image of isolated iron oxide nanoparticles}

The obtained iron oxide nanoparticles possessed spherical shapes with a size of $7 \mathrm{~nm}$.

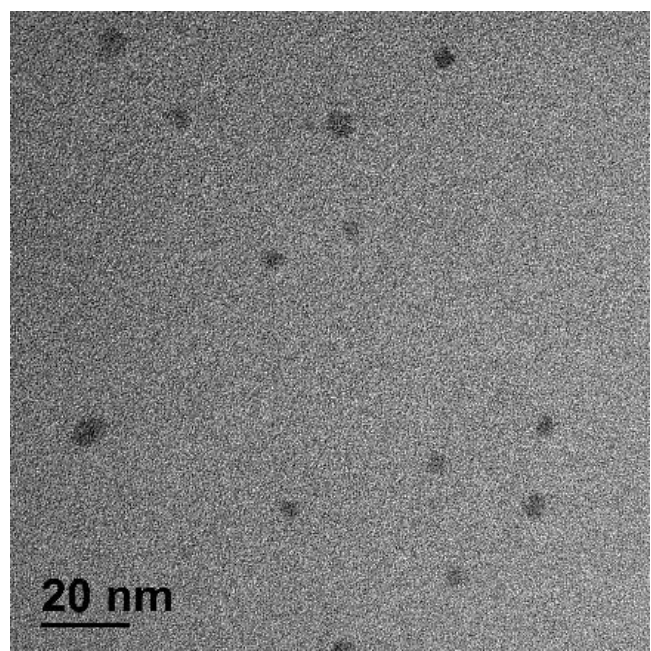

Figure S7. TEM image of $7 \mathrm{~nm}$ isolated iron oxide nanoparticles. 


\section{Zero-field cooling (ZFC) spectra of NCs}

Zero-field cooled (ZFC) curves of the NCs were measured using the SQUID-vibrating sample magnetometer (SQUID-VSM, Magnetic Property Measurement System (MPMS), Quantum Design, Inc, USA) installed at KBSI. The temperature $(5 \mathrm{~K}<T<380 \mathrm{~K})$ dependence of the magnetization curves in an external magnetic field of 50 Oe were recorded in ZFC mode.

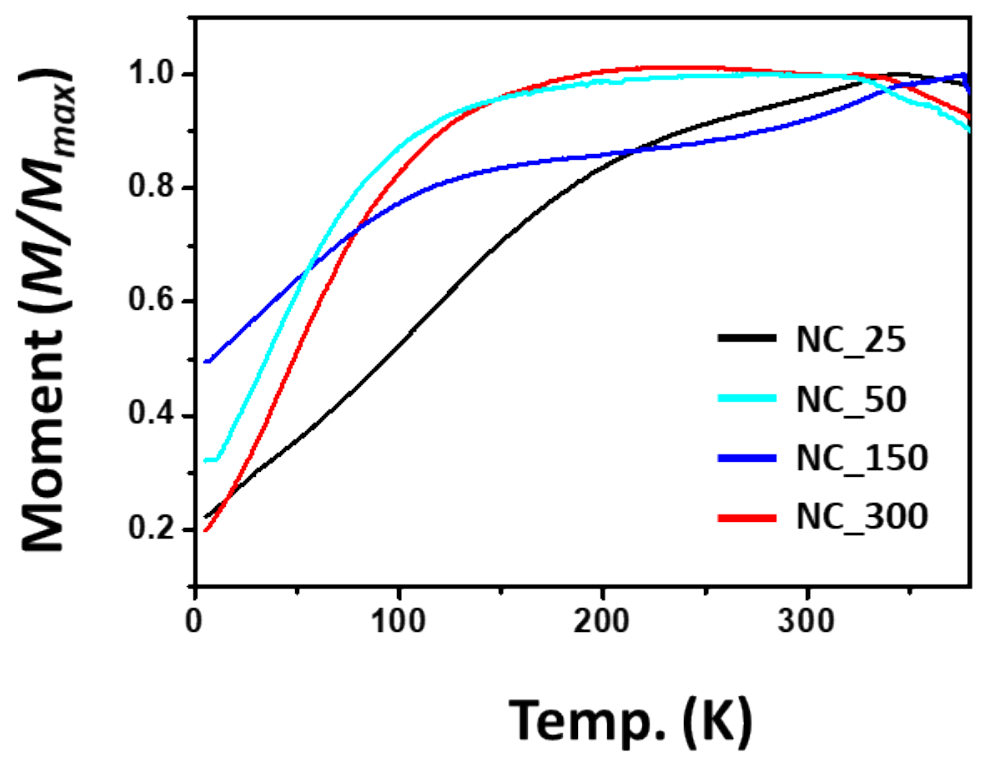

Figure S8. Temperature dependence of magnetization for the zero-field cooled (ZFC) curves of NCs under an applied magnetic field of 50 Oe. 
Low-magnification TEM images of NC_25

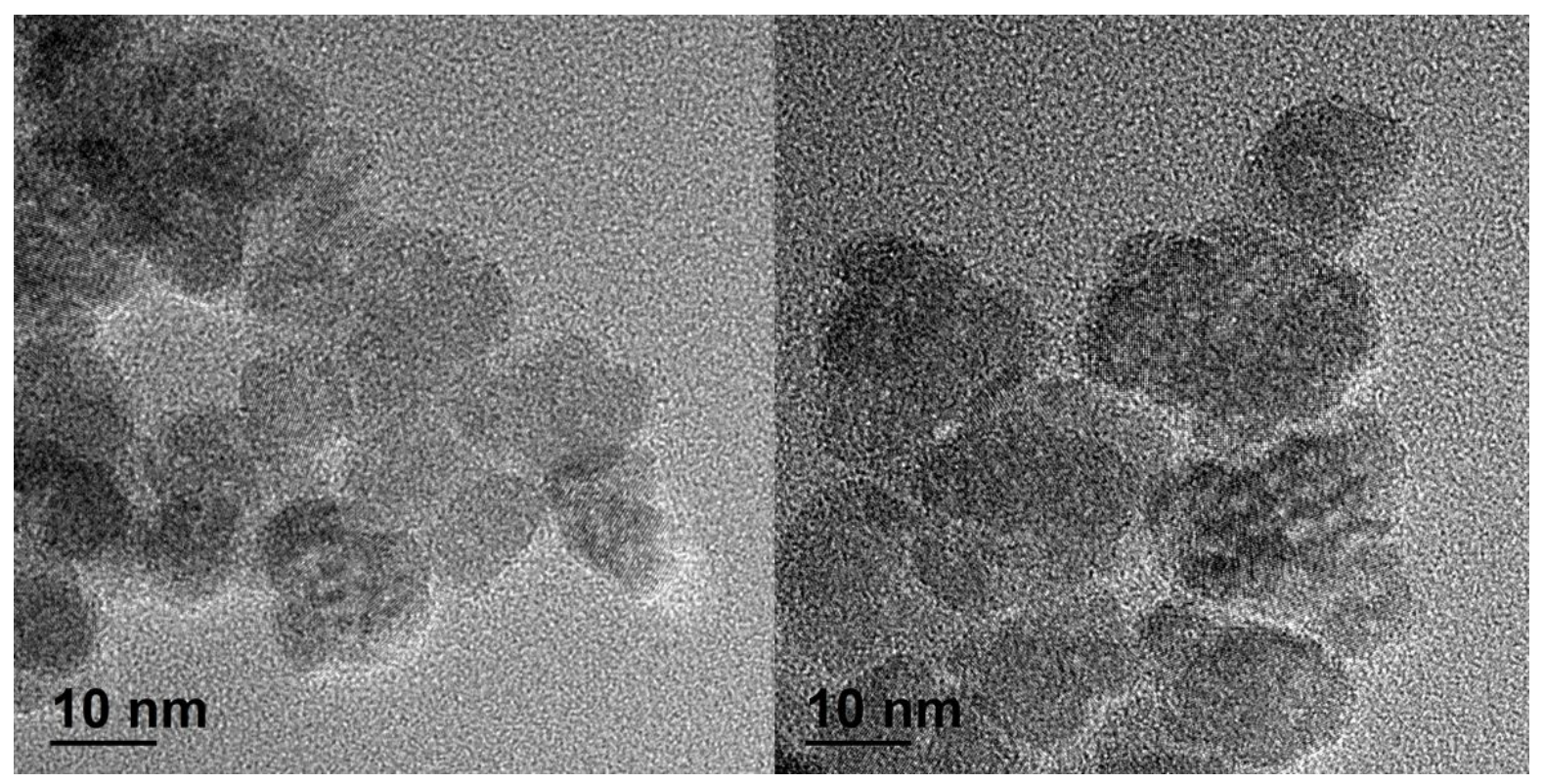

Figure S9. Low-magnification TEM images of NC_25. 


\section{Synthesis of $25 \mathrm{~nm}$ isolated iron oxide nanoparticles (IN_25)}

IN_25 was synthesized through a solvothermal method. First, $1.25 \mathrm{~g}$ of $\mathrm{FeCl}_{2} \cdot 4 \mathrm{H}_{2} \mathrm{O}$ was added to $7.75 \mathrm{~mL}$ of water, and $6.25 \mathrm{~mL}$ of ammonia solution was injected as quickly as possible under vigorous stirring. The mixture was stirred in air for $10 \mathrm{~min}$, then transferred to a Teflon-equipped stainless-steel autoclave and reacted at $134^{\circ} \mathrm{C}$ for $3 \mathrm{~h}$. After the reaction, the product was centrifuged three times with acetone at 10,000 rpm for $3 \mathrm{~min}$. The size of the obtained nanoparticles was measured as $24.6 \pm 5.4 \mathrm{~nm}$.

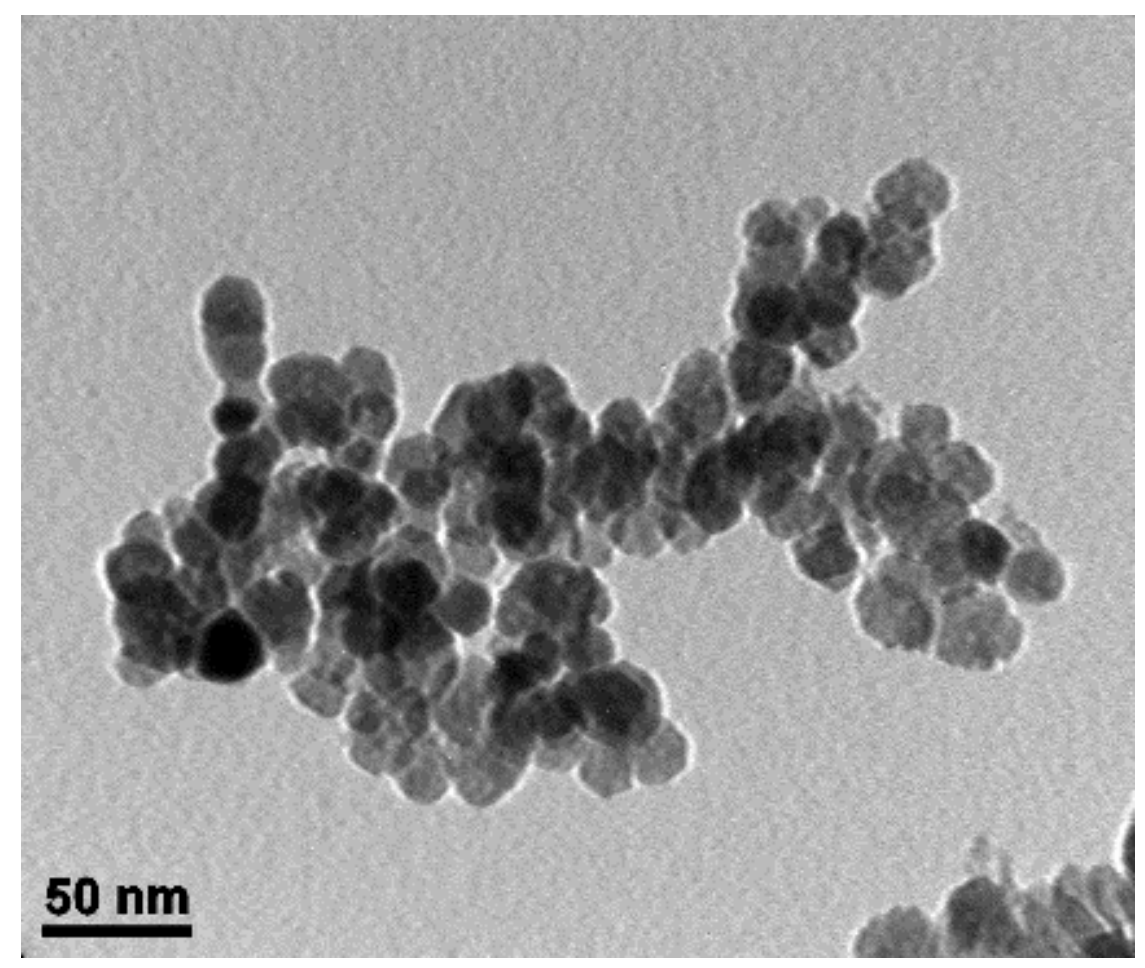

Figure S10. TEM image of IN_25. 


\section{Formation of $25 \mathrm{~nm}$ iron oxide nanoassemblies}

The $25 \mathrm{~nm}$ iron oxide nanoassemblies were synthesized as follows: $2.5 \mathrm{~mL}$ of a $100 \mu \mathrm{M}$ polyallylamine solution was rapidly injected into $2.5 \mathrm{~mL}$ of a solution of the $7 \mathrm{~nm}$ iron oxide nanoparticles at a concentration of $1 \mathrm{mg} \square \mathrm{mL}^{-1}$ under vigorous stirring. After that, the mixture was stirred vigorously for $1 \mathrm{~h}$.

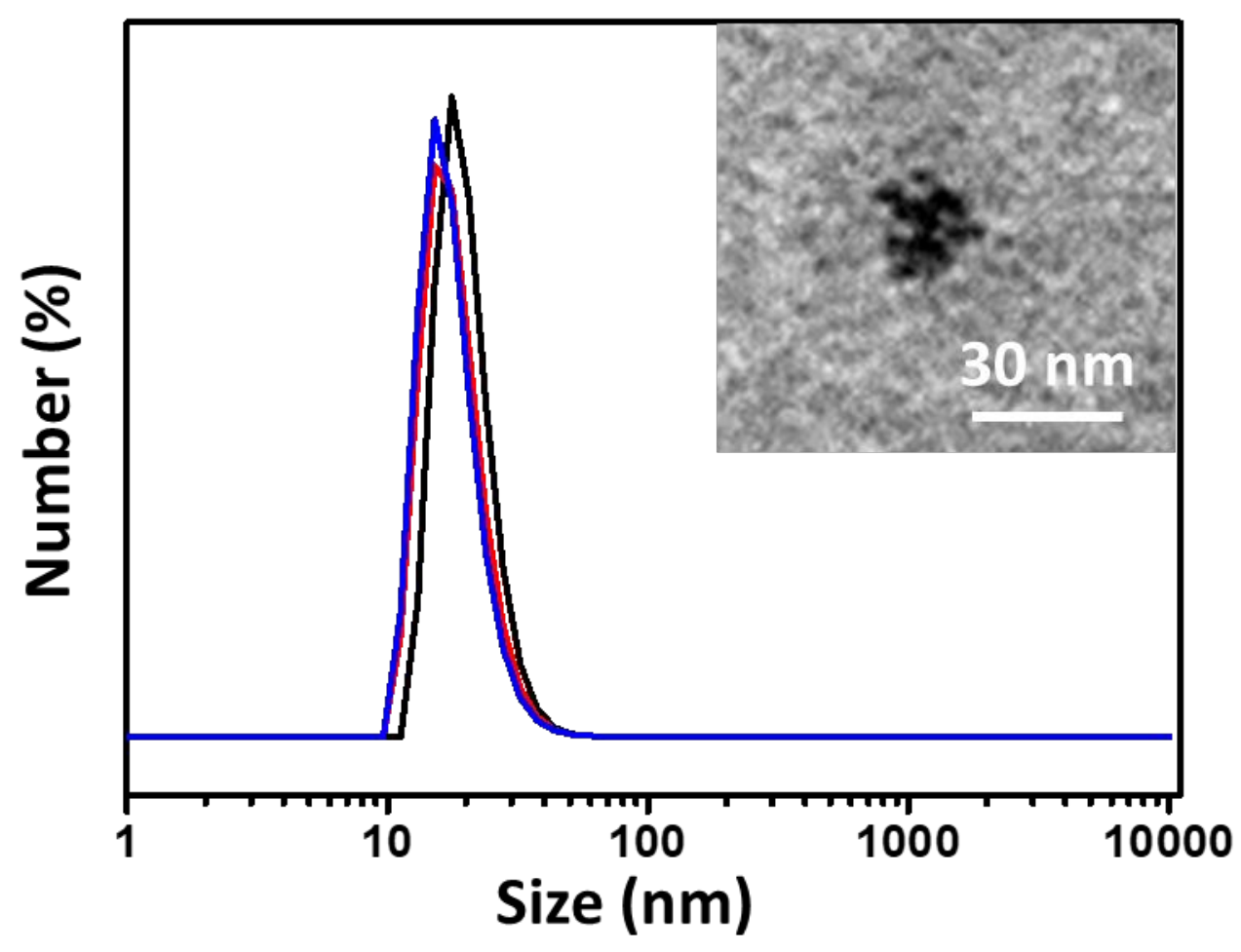

Figure S11. Hydrodynamic size and TEM image (inset) of $25 \mathrm{~nm}$ iron oxide nanoassemblies. 
Comparison of hyperthermia effect of $25 \mathrm{~nm}$ iron oxide particles



Figure S12. Comparison of SLP values of NC_25, IN_25, IN_7, and $25 \mathrm{~nm}$ nanoassemblies. 


\section{Synthesis of Co-doped NCs}

Co-doped $\mathrm{Fe}_{3} \mathrm{O}_{4}$ nanoclusters (Co_NCs) with a size of $200 \mathrm{~nm}$ size were synthesized through a solvothermal method. Briefly, $\mathrm{FeCl}_{3} \cdot 6 \mathrm{H}_{2} \mathrm{O}(0.453 \mathrm{~g})$ and $\mathrm{CoCl}_{2} \cdot 6 \mathrm{H}_{2} \mathrm{O}(0.133 \mathrm{~g})$ were dissolved in 20 $\mathrm{mL}$ of ethylene glycol in the presence of sodium acrylate $(0.25 \mathrm{~g})$ and NaOAc $(3.6 \mathrm{~g})$. Under flowing argon, the mixture was heated to $160^{\circ} \mathrm{C}$ for $1 \mathrm{~h}$ with vigorous stirring, then transferred to a Teflonequipped stainless-steel autoclave and reacted at $200{ }^{\circ} \mathrm{C}$ for $10 \mathrm{~h}$. Co_NCs with a size of $300 \mathrm{~nm}$ were obtained by using PAA $(0.236 \mathrm{~g})$ and sodium acrylate $(0.5 \mathrm{~g})$.

a

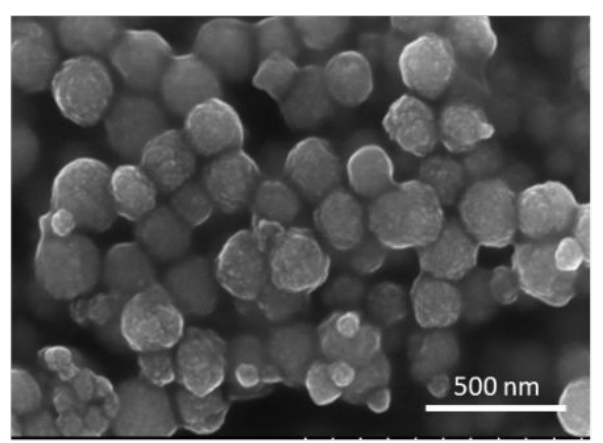

b

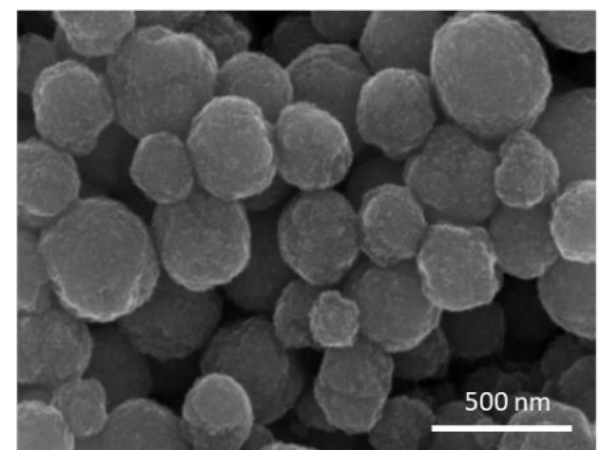



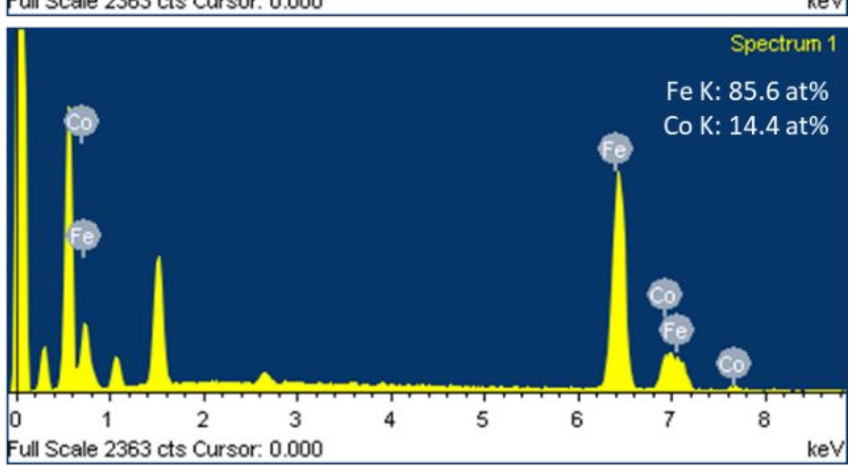

Figure S13. SEM images and EDX data of Co_NCs (a. $200 \mathrm{~nm}$ and b. $300 \mathrm{~nm}$ ). 


\section{Toxicity tests of NCs and Co_NCs}

The biocompatibility and cytotoxicity of the NCs $(25,100,200$, and $300 \mathrm{~nm})$ and Co_NCs (200 and $300 \mathrm{~nm}$ ) were evaluated using human lung cancer cells (A549) and mouse skin cancer cells (B16-T10) via the MTT assay. A549 cells $\left(2 \times 10^{5}\right.$ cells per well) were cultured overnight in a 96-well microtiter plate under a $5 \% \mathrm{CO}_{2}$ atmosphere at $37{ }^{\circ} \mathrm{C}$. The wells were filled with a cell medium containing $\mathrm{NCs}$ or Co_NCs $(\sim 1000 \mu \mathrm{g} / \mathrm{mL})$ and incubated for $24 \mathrm{~h}$. Then, $10 \mu \mathrm{L}$ of the MTT solution was added to each well (final concentration: $0.5 \mathrm{mg} / \mathrm{mL}$ ). After incubation for $4 \mathrm{~h}$, formazan, which is generated from the reduction of MTT by $\mathrm{NAD}(\mathrm{P}) \mathrm{H}-$ dependent oxidoreductase in living cells, was dissolved in the solubilization solution of the kit. The absorbance at $600 \mathrm{~nm}$ was measured using a microplate reader (SpectraMax M2e, Molecular Devices, LLC, USA).


Figure S14. Viability tests of (a,c) NCs and (b,d) Co_NCs. The viability of A549 (a,b) and B10-T16 $(c, d)$ cells was examined using the MTT assay, in which the cells were treated with a cell medium containing the NCs or Co_NCs for $24 \mathrm{~h}$. 